\title{
INDEX TO VOLUME 41
}

\section{ARTWORK}

Beckman, Christopher, Iowa Courtroom Series, 3/112

Crompton, Stephen J., Realizing Edward Hopper, 1/113

Regas, Angela, State Fair, 2/42

\section{ESSAYS}

Deulen, Danielle Cadena, Aperture, $1 / 84$

Dohrmann, Sarah, Point of Departure, 2/171

Lindenberg, Rebecca, Archipelago, 3/142

Lohafer, Susan, In the Bullring, 1/63

Newberry, Jacob, December in the Pyrenees, 3/40

Nicorvo, Jay Baron, Summer Chickens, 1/98

Nix, Megan, Uncles, 2/89

Phillips, Helen, Life Care Center, 3/18

Purpura, Lia, Jump, 2/115

Rapoport, Maria, City by the Woods, 3/59

Sandor, Jane, Doctor Trixie Beau's Advice to the Uninsured, 2/2

Sasaki, Fred, Punch No. 96, 1/3

\section{INTERVIEWS}

Dezen, Alex, Sex, Rocks, and Taxidermy: A Conversation with Chris Offutt, 3/117

Fay, Sarah, Fiction Born of Rival Impulses: A Conversation with Wells Tower, 1/103

POEMS

Balbo, Ned, From a Son of Marco Polo in the Village of Blue People, 2/14

Bang, Mary Jo, Canto X, 2/66

Canto XI, $2 / 74$

Canto XII, 2/81

Bernheim, Erica, The Oversized World, 1/117

[when I say backdoor I mean the way a lot], 1/119

Elegy In The Absence Of, 1/120

Burwick, Kimberly, The Therapists Say to Admit the Nature of You, 3/27

And Want Shall Shun You, 3/28

THE IOWA REVIEW 
Panhandle, 3/29

The Sister, $3 / 30$

Everything Lush I Know, 3/31

Gold Markings, $3 / 32$

The Past Is Not Sweet to Us, $3 / 33$

Unglamorous, 3/34

South Teton, Hypoxia, 3/35

If You Are a Beggar They Lower You Softly, 3/36

Collins, Martha, [white paper \#1], 3/106

[white paper \#11], 3/107

[white paper \#19], 3/108

[white paper \#27], 3/110

[white paper \#45], 3/111

Economou, George and Yiorgos Chouliaras, 3x3, 2/98

Kassandra's Story, 2/99

Emperor, 2/103

Day of Disembarkation, 2/105

The Barbarians Are Not Waiting, 2/107

Il Gran Veglio di Creta, 2/109

End Riddle, 2/111

Eklund, George, They Called Me the Prince, 3/140

Outside the Small Mexican Market, 3/141

Feld, Andrew, There, 2/161

Guide, 2/164

Guide, 2/167

Ginsburg, Melissa, Squab, 1/29

Our Hospital, 1/30

Preserve, $1 / 31$

Drift, $1 / 32$

Kinsella, John, First Lines Typed at Jam Tree Gully, 3/79

Digging, 3/82

Dream of What's Below, $3 / 84$

Kosick, Rebecca; see Rubio, Fanny

Kryah, Joshua, The Least Child, 1/157

Poor Dogsbody, Poor Dogsbody's Body, 1/158

That Man to Man Is an Arrant Wolfe, 1/159 
Playlist of the Same, $1 / 160$

We Are Starved, 1/161

Lauer, Brett Fletcher, Severance, 2/123

No Matter the Details, 2/125

Lerner, Ben, Late in the Form, $1 / 78$

Late in the Form, 1/79

Lozano, Kim, Letter from a Mental Hospital, 2/184

Class Reunion, 2/185

McMorris, Mark, Letters to Michael, 3/165

Moritz, Rachel, Nativity, 2/147

Nealon, Chris, Poem (We file like pilgrims...), 3/16

Pink Marble, 3/17

Posna, Lee, Theseus, $1 / 80$

Behind the Counter, $1 / 81$

Rahman, Ruby (transl. by Carolyne Wright), Damages, 1/132

House of the Universe, 1/133

See, If You Can, $1 / 135$

194 Rubio, Fanny (transl. by Rebecca Kosick), Root, 3/42

The Last of the South, 3/44

Grenzenborders, 3/46

Schorsch, Mike, An Introduction to Venantius Fortunatus for Schoolchildren, or

Understanding the Medieval Concept World through Metonymy: A Beginner's

Book., 2/33

Trinidad, David, Sharon Tate and Friends the Moment Before, 1/33

Medusa Redux, 1/34

Noir \& Blanc, $1 / 37$

Van Kley, Emily, You Aren't Sure \& I May Not, 3/47

Premises, 3/50

My Dead Grandfather, 3/52

After Winter, 3/54

Weight Training, 3/55

Menstrual, 3/57

Wills, Jackson, from Inter Umbras Arborum, a Pastoral Phantasm-agoria, 1/162

Witte, John, $Y, 1 / 95$

Jesus and the Splinter, 1/96

When You Come to Lethe, 1/97

Wright, Carolyne; see Rahman, Ruby

THE IOWA REVIEW 
STORIES

Almond, Steve, What Retired Engineer Roger Mudge Thinks Upon His Son Patrick's Announcement of His Engagement, 1/137

Testimony of a Private, $1 / 138$

The Short Goodbye, 1/139

Bazzle, Bradley, Magellan, 3/1

Dillman, Lisa; see Halfon, Eduardo

Dybek, Stuart, Here Comes the Sun, 1/82

Fleming, Colin, Padraig and Lorcan, 3/95

Halfon, Eduardo (transl. by Lisa Dillman), Distant, 2/127

Houston, Pam, Contents May Have Shifted, \#49-\#6o, 1/48

Kelly, Boris, Mow, $3 / 37$

Lisicky, Paul, Irreverence, $1 / 72$

Bunny, 1/74

The Mother Sits Down on the Bed, 1/75

The End of England, 1/76

Moffett, Kevin, The Perfect Age, 1/13

Morgan, Speer, The God Pocket, 2/17

Ockert, Jason, Max, 1/140

Offutt, Chris, Eclipse, 3/128

Ostlund, Lori, The Lent Boy, 2/186

Reinbold, Craig, Girl on Tracks, 3/71

Rosenblum, Sophie, Core, Mantle, Crust, Crust, Mantle, Core, 2/183

Ruch, Alison, Safe, 3/155

Scanlon, Suzanne, Her Thirty-Seventh Year, An Index, 3/85

Shoemaker, Jeanne, Sonny Criss, $2 / 47$

Starkey, Laurel, Eating Potato Salad on the Lawn of the Damned, 1/122

Terry, James, Road to Nowhere, 1/165

Van Kirk, John, Landscape with Boys, 3/169

Wurzbacher, Ashley, Burden, 1/38

Zhang, Jenny, You Fell into the River and I Saved You!, 2/150 